\title{
FY95 Capital Asset Implementation Plan
}

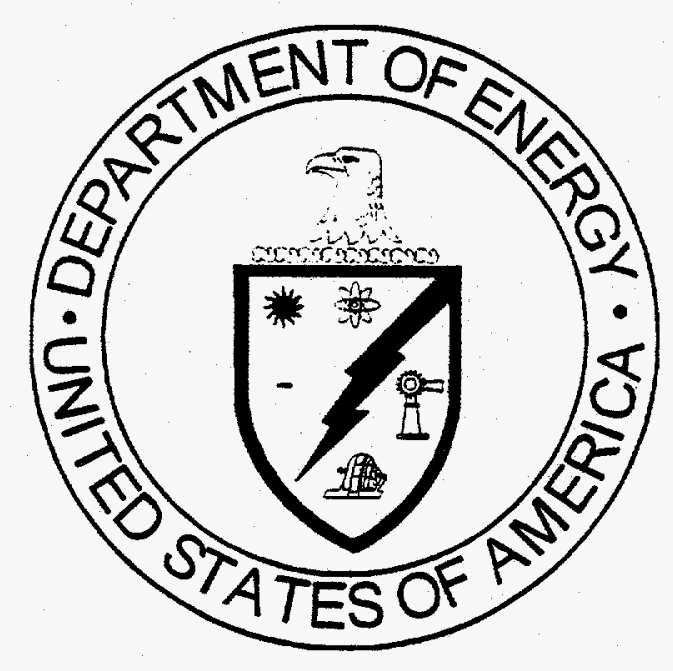

December 1994

\section{Prepared for \\ United States Department of Energy}

Westinghouse Electric Corporation Waste Isolation Division

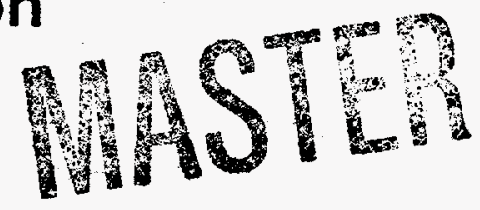

This document supersedes the FY94 Capital Asset implementation Plan DIGTRIBUTION OF THS DOOUMENT IS UMLIMTED TP 


\section{DISCLAIMER}

Portions of this document may be illegible in electronic image products. Images are produced from the best available original document. 


\section{DISCLAIMER}

This document was prepared as an account of work sponsored by an agency of the United States Government. Neither the United States Government nor any agency thereof, nor any of their employees, makes any warranty, express or implied, or assumes any legal liability or responsibility for the accuracy, completeness, or usefulness of any information, apparatus, product or process disclosed, or represents that its use would not infringe privately owned rights. References herein to any specific commercial product, process, or service by trade name, trademark, manufacturer, or otherwise, does not necessarily constitute or imply its endorsement, recommendation, or favoring by the United States Government or any agency thereof. The views and opinions of authors expressed herein do not necessarily state or reflect those of the United States Government or any agency thereof.

This document has been reproduced directly from the best possible copy. It is available to DOE and DOE contractors at the following address:

Office of Scientific and Technical Information

P. O. Box 62

Oak Ridge, TN 37831

Prices available from (615) 576-8401

Available to the public from the National Technical Information Service

U. S. Department of Commerce 5285 Port Royal Road Springfield, VA 22161

Processing and final preparation of this report was performed by the Waste Isolation Pilot Plant Management and Operating Contractor for the U.S. Department of Energy under Contract No. DE-AC04-86AL31950. 


\section{EXECUTIVE SUMMARY}

The Waste Isolation Division (WID) is committed to providing good stewardship for the capital assets under its operational and physical control. To achieve this goal, the WID has developed the Capital Asset Implementation Plan (CAIP) to continue to implement for FY95 Department of Energy (DOE) Order 4320.2A, Capital Asset Management Process (CAMP). The Order provides policy and elements needed to establish a credible, consistent, auditable, and technically sound process for the DOE to forecast, plan, and budget for capital assets on a functional unit level.

The objective of the WIPP CAMP program is to meet the goals of DOE Order $4320.2 \mathrm{~A}$ in the most effective and efficient manner possible in support of the Waste Isolation Pilot Plant (WIPP) mission. As a result, this CAIP provides a way to implement the CAMP Program using a graded approach. Continued implementation will be accomplished by improving the existing process, and establishing future goals to promote growth for the CAMP Program.

The CAIP is issued annually by the WID with quarterly progress reports submitted to the DOE. This document describes the current-year program staffing, roles, responsibilities, funding, and near-term milestones. In addition, the results of past goals are discussed. 
TABLE OF CONTENTS

EXECUTIVE SUMMARY

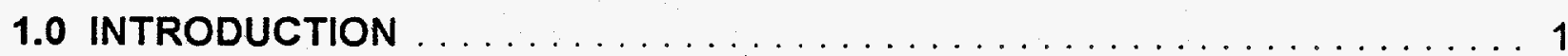

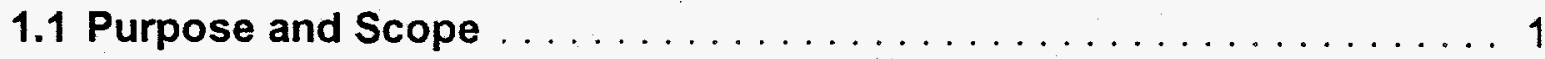

1.2 Implementation Approach for Fiscal Year (FY) $1995 \ldots \ldots \ldots \ldots \ldots 1$

1.3 Extent of Current Compliance $\ldots \ldots \ldots \ldots \ldots \ldots \ldots \ldots \ldots \ldots \ldots$

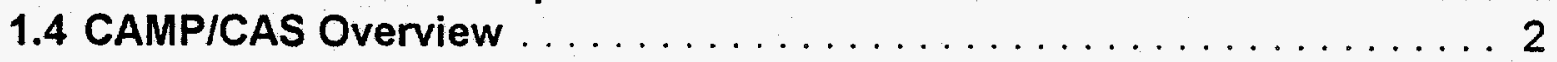

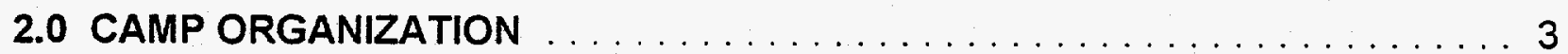

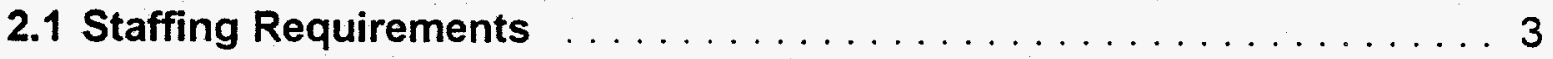

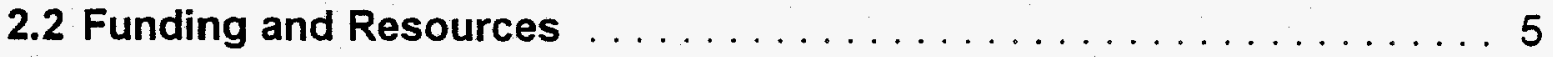

3.0 RESULTS OF FY94 MILESTONES $\ldots \ldots \ldots \ldots \ldots \ldots \ldots \ldots$

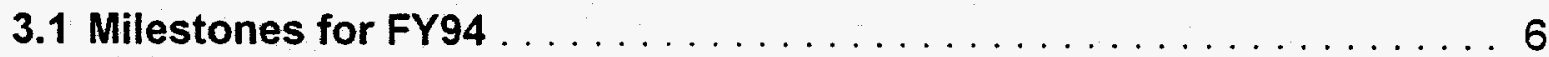

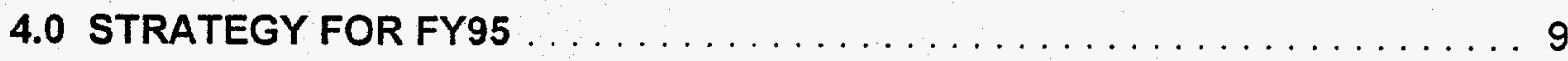

4.1 IMPLEMENTATION MILESTONES $\ldots \ldots \ldots \ldots \ldots \ldots \ldots \ldots$

APPENDIX A WIPP LAYOUT DIAGRAMS

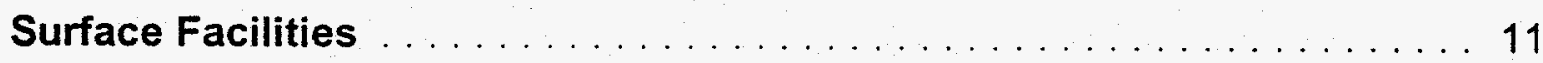

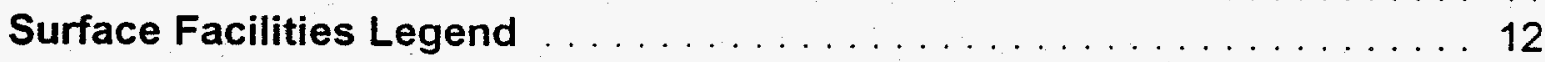

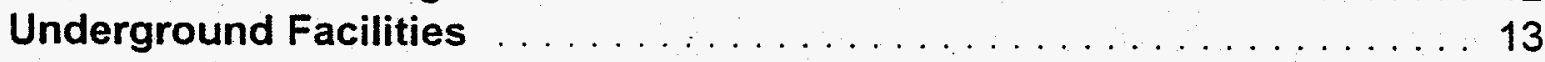

Underground Facilities Legend $\ldots \ldots \ldots \ldots \ldots \ldots \ldots \ldots \ldots \ldots$

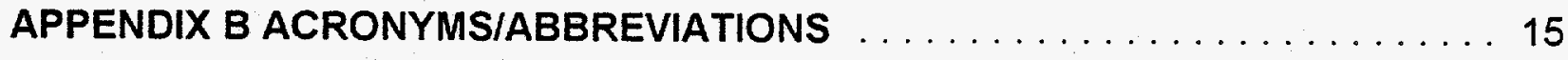

APPENDIX C GLOSSARY OF TERMS $\ldots \ldots \ldots \ldots \ldots \ldots \ldots \ldots$

APPENDIX D ORGANIZATIONAL CHART $\ldots \ldots \ldots \ldots \ldots \ldots \ldots \ldots \ldots$

APPENDIX E INSPECTION SCHEDULE $\ldots \ldots \ldots \ldots \ldots \ldots \ldots$ 


\subsection{INTRODUCTION}

\subsection{Purpose and Scope}

The purpose of this plan is to continue implementation of DOE Order 4320.2A, Capital Asset Management Process (CAMP), at the WIPP. The CAMP Order, revised in February 1994, applies to all capital assets the DOE owns, leases, or controls for production, operation, research, development, or demonstration, except for those specifically excluded by the order, statute, or separate delegation of authority from the Secretary of Energy.

The WID takes great pride in maintaining the condition of all DOE capital assets under its cognizance. The CAMP is expected to become a valuable tool in continuing this good stewardship. This plan applies to the property, buildings, and equipment managed by the WID, the WIPP's management and operating contractor.

\subsection{Implementation Approach for Fiscal Year (FY) 1995}

This plan outlines strategies to maximize the impact of CAMP funding received by applying these funds in a manner consistent with the WIPP mission and goals of the CAMP Order. These strategies include: Continued implementation of the Condition Assessment Survey (CAS) Program; Integration of Site Development Planning; and Expansion of the CAMP Report to include anticipated maintenance expenditures, capital equipment expenditures, and long-term planning.

The CAIP addresses the following issues:

- FY94 objectives and results

- Near-term CAMP objectives (FY95)

- Long-term CAMP objectives (FY96-FY17)

- CAMP organization, including defined roles and responsibilities

- Funding requirements

- Implementation milestones

\subsection{Extent of Current Compliance}

CAS inspections are being performed on site to gain information for facilities and equipment owned by the DOE. Through utilization of a graded approach, buildings, utilities, and major capital equipment based on importance, age and use were selected as assets to be inspected. 
The Condition Assessment Information System (CAIS), the computer support for the CAS and CAMP programs, has been implemented. A full annual cycle of CAS inspections and CAIS reporting is needed to identify improvements to be made. The cycle will be completed in June 1995.

\subsection{CAMP/CAS Overview}

DOE Order 4320.2A established policy and responsibilities for the management of DOE capital assets and provides for a consistent prioritization methodology for determining the preferred order for allocating limited resources for maintenance of those assets. CAMP has five major elements:

1. Functional Unit Breakdown Structure (FUBS)

2. Condition Assessment Surveys (CAS)

3. Life Cycle Planning (LCP)

4. Prioritization Process

5. Functional Unit Data Sheets (FUDS)

The purpose of the CAS Program is to inspect the physical condition of buildings, structures, utilities, and selected equipment using several resources which include CAS inspectors, CAS tools, and CAIS support. Other inspections performed by the designated site personnel, such as preventive maintenance inspections, landlord inspections, industrial safety inspections, and others contribute valuable information about the condition of the WIPP's capital assets that can be used to support CAS.

LCP is accomplished by evaluating CAS inspection information to decide what repairs, replacement, or modifications are required to maintain the assets over the life of the mission. Maintenance, resource, and future project needs are discussed in the CAMP Report to provide a planning horizon for DOE owned assets.

Projects determined through the CAS and LCP processes are ranked using the CAMP prioritization tables. A baseline is then established for out-year planning and budgeting. An annual CAMP Report is issued which describes all CAMP elements in detail, including CAS results, LCP analysis, and project descriptions. This ultimately provides a picture of anticipated projects, resources, and funding needed to sustain the facility over the life of the mission. 


\subsection{CAMP ORGANIZATION}

\subsection{Staffing Requirements}

Four personnel positions have been allocated for the WID CAMP Organization. This staffing level requires personnel cross training to meet the stated purposes and objectives of the CAMP Order.

The administrative responsibilities are delineated below:

\section{CAMP/CAS Program Coordinator}

Reports directly to the cognizant Maintenance Operations Manager and has responsibility for establishing and implementing the WIPP CAMP Program. The CAMP Program Coordinator is the focal point at the WIPP, and is responsible for the direct planning and execution of the WIPP CAMP Program.

Responsibilities:

- Ensures CAMP reporting is performed in accordance with DOE guidance, allocated funding, and within the prescribed time frame

- Provides informal training for non-CAMP site personnel

- Ensures the CAMP/CAS/CAIS group obtains adequate training and maintains the appropriate level of authorization to conduct the program in a credible and technically sound manner

- Evaluates CAS inspection results and ensures consistency

- Ensures the results of other inspection programs are included in the CAMP Process (i.e. landlord inspections, safety inspections, etc)

- Ensures appropriate information is extracted from the CAIS database, site development, and other programs for use in prioritizing site maintenance actions and for inclusion in the CAMP Report

- Reviews and approves CAS inspection schedules

- Ensures the CAS inspection program is conducted in a formal, consistent, and auditable manner 


\section{CAS Inspector}

Reports directly to the CAMP Program Coordinator. The CAS Inspector is responsible for conducting CAS inspections and reporting deficiencies.

Responsibilities:

- Ensures WIPP CAS inspections are performed and deficiencies recorded

- Ensures deficiencies requiring immediate action are brought to the attention of appropriate management

- Reviews results of other inspection programs for incorporation into the CAMP Process

- Prepares CAS inspection reports

- Coordinates CAS inspections with other inspection teams or departments

- Generates action or first request if near-term remedial action is required

\section{CAIS Coordinator}

Reports directly to the CAMP Program Coordinator on matters relating to the CAIS, and is responsible for the WIPP CAIS hardware, software, and database.

Responsibilities:

- Maintains the site CAIS computer and associated software

- Updates the CAIS database

- Incorporates asset information in the system for inspection purposes

- Ensures appropriate assignments are made for each asset to its corresponding functional unit (FU) code

- Prepares Data Collection Device (DCD) for inspection use

- Ensures specific information is available in the CAIS to generate reports

- Prepares database reports for analysis and incorporation into the CAMP report 


\subsection{Funding and Resources}

The following is a breakdown of the available funding and resources for FY95. Future funding needs will be based on CAIS hardware/software requirements, training, and additional guidance provided by the DOE. In FY96, an upgrade to Oracle 7 is anticipated to enhance the effectiveness of the CAIS.

Personnel

CAMPICAS Program Coordinator

CAIS Coordinator

CAS Inspector

TOTAL

Funding Profile

Travel

Training

Material/Supplies

\section{FTES}

1.0

1.0

2.0

4.0

$\$ K$

6.6

2.0

$\underline{0.6}$

9.2 


\subsection{RESULTS OF FY94 MILESTONES}

\subsection{Milestones for FY94}

The primary goal was to establish a CAMP process on site. Accomplishing this goal included selection of staff, procurement and installation of CAIS hardware and software, determination of the Functional Unit Breakdown Structures, issuance of the first WIPP CAMP Report, and implementation of CAS.

The CAMP group was formed in October 1993. The following discusses the strategies that were established for FY94, and the results of each.

\section{Personnel Selection and Training}

Initial staffing and assignments changed in April 1994, resulting in the loss of two inspectors. Two new inspectors joined the team in April, forming the foundation of the CAS inspection group. Training for inspectors has been accomplished for three inspectors; training for the remaining inspector is anticipated by March 1995.

In addition, authorization cards were developed for each specific inspection discipline: electrical, mechanical, and civil/architectural. The authorization card verifies the inspectors expertise and knowledge of the task. The cards were developed in January 1994.

\section{Define WIPP Functional Unit Breakdown Structure}

CAMP assets are classified into similar groups based on their function, rather than their mission. The similar groups of assets are specified as FUs. The DOE Order specifies 30 FUs and their descriptions. WIPP uses 19 FUs split into buildings, structures, and equipment.

CAMP FUs were completed in February 1994.

\section{Develop Life Cycle Plans for FUS}

WIPP LCPs describe the major activities in the life of a FU from planning through decommissioning. Asset function, characteristics, future mission, condition, maintenance planning, and future projects are included in each LCP. Once FUs were established, research was done to determine characteristics and mission.

Several interface documents were utilized to incorporate information into the LCP due to the limited time needed to accomplish the task. The General Plant Design Descriptions, the Comprehensive Underground Management Plan, the Site Development Plan, and other direct interfaces were used to locate appropriate information. CAMP LCPs were completed in March 1994. 


\section{Issue First WIPP CAMP Report}

The FY96 CAMP Report was issued in April 1994. The report described WIPP's FUs, their corresponding LCPs, and anticipated projects for FY95 and FY96. All projects were required to have Functional Unit Data Sheets (FUDS), which outlined the activity description, justification and funding profile. Support from Operations, Engineering, Safety, and Maintenance was instrumental in issuing the report.

\section{Implement CAIS Hardware and Software}

Procurement of the CAIS occurred in January 1994, and system set-up and software installation was completed in May 1994. The Real Property Inventory System (RPIS) was verified for accuracy and uploaded into the CAIS for data manipulation. Selected RPIS identification numbers were assigned to a CAMP Functional Unit (FU). This was done because several RPIS designators were not assigned the correct usage code. FUs, based on asset usage, are the basis for CAMP planning. After FU assignment, asset characteristics were researched and input into CAIS to aid in CAS inspections.

FU assignment and limited asset characteristic entry into the CAIS was completed in May. Expanded characteristics are being entered as inspections are being performed. CAIS reporting, including inspection detail reports and costing, are ongoing.

\section{Establish a Graded Approach for CAS Inspections}

After issuance of the CAMP report, a CAS inspection schedule was developed. Buildings, utilities, and major capital equipment based on importance, age, and use were selected as assets to be inspected. The CAS inspection schedule was additionally developed to parallel the preventive maintenance schedule. Recent schedule enhancements have provided the inspectors a two week look-ahead for planned preventive maintenance. As a result, the CAS inspectors can schedule inspections in conjunction with scheduled maintenance to prevent repetitive equipment downtime.

The initial CAS inspection was performed in May on the 700A Fan, a critical component for underground ventilation. Inspections and reports are being processed weekly.

All milestones established in the FY94 CAIP were completed on or ahead of schedule. The milestone to develop site specific Deficiency Standards and Inspection Methods Manual has been deleted. DOE has a singular contractor to develop Volume 10, which will contain deficiency standards not included in other volumes. Input for WIPP unique assets has been transferred to the contractor in August 1994 to provide DOE with possible information to expand their manuals.

In addition to meeting all FY94 CAIP milestones, three additional accomplishments were completed. First, after reviewing the applicable Work Breakdown Structures (WBS) in the DCD, it was found that several pieces of unique assets existed at WIPP with no WBS. Therefore, DCD inspections could not be performed. WIPP developed 
an inspection process for non-DCD inspections to provide condition information on unique assets that are listed in the CAMP report.

Second, a CAMP Program Plan was drafted outlining how the CAMP Report is created. Descriptions of interfaces, responsibilities, and useful information is discussed. Most importantly, the criteria for how WIPP arrived at its FU grouping, and resulting LCP are shown. This enables readers to understand the process behind the initial CAMP report.

Lastly, the CAS inspection team took over the facility condition inspections previously performed by Plant Engineering, although their continued inspection support is provided through Cognizant Engineer reviews, and CAS inspection walkdowns. The facility condition inspections, more oriented towards cleanliness and housekeeping, do contain certain elements of CAS. It was determined that the facility condition inspection scope could be combined into the CAS effort thereby avoiding significant duplication of effort. 


\subsection{STRATEGY FOR FY95}

In addition to preparing WAD deliverables, performing CAS/CAMP and associated duties, several new goals have been established for CAMP in FY95. The following lists the goals for the upcoming year.

\section{Goal 1 - Use CAS Results in FY97 CAMP Report}

The first goal is to use CAS inspection results in the FY97 CAMP Report, because inspection data was not available for the first report. Evaluation of CAS results will aid in the determination of repair, replacement, or modification needs over the assets mission life. This will improve the description of deficiencies, provide a baseline for future inspections and reports, and supply justification for projects.

\section{Goal 2 - Evaluate CAS to Make Needed Improvements}

After issuance of the FY97 CAMP Report, an evaluation of the first year's inspection process will be completed. Types of improvements include: deleting unnecessary inspections; altering frequency of inspections; adding new inspections; and revising the reporting process if information could be represented more effectively.

\section{Goal 3 - Expand Report to Include Other Information}

Because the CAMP Report is informative, suggestions have been made to expand the report slightly and add additional funding information. The goal is to include not only General Plant Project information, but also future high-dollar maintenance and capital equipment expenditures, and operating expense funded projects. In addition, forecasts of changes in funding or resources for major assets will be made to contribute to the future planning of the site. Information previously contained in the Comprehensive Underground Management Plan will be incorporated into the CAMP report to provide anticipated expenditures in the underground. To provide a true representation of anticipated expenditures and projects in the future, a long-term focus on the total resource requirements of the site is imperative.

The key is to involve site development planning in the CAMP Process. Site development issues concern future planning and development which affect facilities, utilities, and equipment. The incorporation of site development considerations is critical to identify future needs. 


\subsection{IMPLEMENTATION MILESTONES}

Quarterly CAIP

CAS/CAIS Training

Draft LCP

Draft FUDS

Quarterly CAIP

FY97 CAMP Report

Evaluate CAS FY94/95

Quarterly CAIP

Quarterly CAIP
January 95

January 95

February 95

March 95

April 95

April 95

May 95

July 95

October 95 
APPENDIX A

WIPP LAYOUT DIAGRAMS

Surface Facilities

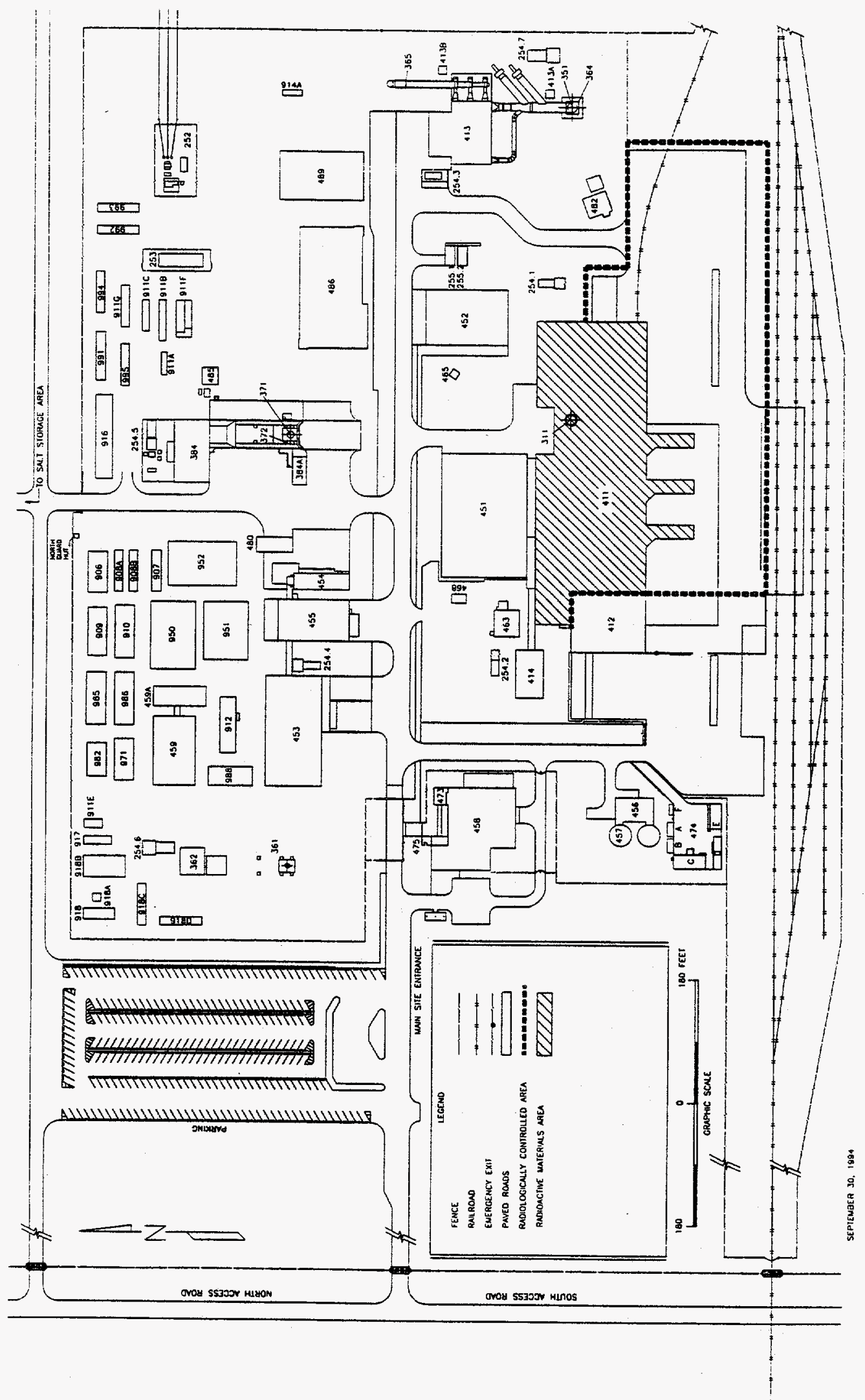


APPENDIX A

WIPP LAYOUT DIAGRAMS

Surface Facilities Legend

\section{FACILITIES, USAGE AND STRUCTURE NUMBERS (FY 1995)}

SPS UTILITY SUBSTATION

13.8 KV SWITCHCEAR 25P-SWG $15 / 9$

AREA SUBSTATION NO. 1 2SP-SW15.1

AREA SUBSTATION NO.2 25P-SW 15.2

AREA SUBSTATION NO.3 25P-SW 15.3

AREA SUBSTATION NO.4 25P-SW15.4

AREA SUBSTATION NO.5 25P-SW15.5

AREA SUBSTATION NO.6 25P-SW15.6

AREA SUBSTATION NO.7 25P-SW15.7

EMERGENCY GENERATOR \#1 25-PE 503

EMERGENCY GENERATOR \#2 25-PE 504

WASTE SHAFT

EXHAUST SHAFT

AIR INTAKE SHAFT

AIR INTAKE SHATT/WINCH HOUSE

EFFLUENT MONITORING INSTRUMENT SHED - "A"

EFFLUENT MONITORING INSTRUMENT SHED - " $\Xi "$

SALT HANDLING SHAFT

SALT HANDLING SHAFT HEADFRAME

SALT HANDLING SHAFT HOISTHOUSE

UNDERGROUND SERVICES OFFICE

WASTE HANDLING BUILDING

TRUPACT MAINTENANCE BUILDING

EXHAUST SHAFT FILTER BUILOING

MONITORING STATION "A"

MONITORING STATION "B"

WATER CHILLER FACILITY

SUPPORT BUILDING - OFFICES. ETC.

SAFETY \& EMERGENCY SERVICES FACIUITIES

WAREHOUSE/SHOPS BUILDINC

VEHICLE SERVICE BUILDING

AUXILIARY WAREHOUSE BUILDING - MAINTENANCE

WATER PUMPHOUSE

WATER TANKS

GUARD AND SECURITY BUILDING

CORE STORAGE GUILDING

DBL WIDE TRAILER - OFFICE

COMPRESSOR BUILDING

AUXILIARY AIR INTAKE

TELEPHONE HUT

ARMORY BUILDING - ARMORY AND LOCK SHOP

HAZARDOUS WASTE STORAGE AREA

GATEHOUSE - MAIN SITE ENTRANCE/EXIT
FAC 252

FAC 253

FAC 254.1

FAC 254.2

FAC 254.3

FAC 254.4

FAC 254.5

FAC 254.6

FAC 254.7

FAC 255.1

FAC 255.2

FAC 311

FAC 351

FAC 361

FAC 362

FAC 364

FAC 365

FAC 371

FAC 372

FAC 384

FAC 384A

BLD 411

BLD 412

BLD 413

BLD 413A

BLD $413 B$

FAC 414

BLD 451

BLD 452

BLD 453

BLD 454

BLD 455

8LD 456

FAC 457

BLD 458

BLO 459

BLD 459A

BLD 463

FAC 465

BLD 468

BLD 473

FAC 474

BLD 475
VEHICLE FUEL STATION

EXHAUST SHAFT HOIST EQUIPMENT WAREHOUSE

SULLAIR COMPRESSOR BUILDING

ENGINEERING BUILDING - OFFICES

TRAINING BUILDING

DBL. WIDE TRAILER - OFFICE

SINGLE WIDE TRAILER - OFFICE

SINGLE WIDE TRAILER - CABLE FABRICATION

SINGLE WIDE TRAILER - OFFICE

DBL. WIDE TRAILER - OFFICE

DBL. WIDE TRAILER - OFFICE AND LAB

SINGLE WIDE TRAILER - OFFICE

SINGLE WIOE TRAILER - OFFICE

SINGLE WIDE TRAILER - OFFICE

SINGLE WIDE TRAILER - AIS STAGING

OBL. WIOE TRAILER - COMPUTER CENTER

SINGLE WIDE TRAILER - CABLE FABRICATION

DQL. WIOE TRALER - OFFICE AND CLASSROOMS

SINGLE WIDE TRAILER - OFFICE

SINGLE WIDE TRAILER - OFFICE

TRAILER COMPLEX (4) - OFFICE

SINGLE WIDE TRAILER - AIS DATA AOUISITION

SINGLE WIDE - OFFICE

VOC AIR MONITORING STATION

VOC LAB TRAILER

TRAILER COMPLEX (7) - OFFICE

TRAILER COMPLEX (6) - OFFICE

TRAILER COMPLEX (7) - OFFICE

DBL WIDE TRAILER - OFFICE

DBL. WIDE TRAILER - OFFICE

DBL. WIDE TRAILER - OFFICE

DBL. WIDE TRAILER - OFFICE

DBL. WIDE TRAILER - OFFICE

SINGLE WIDE TRAILER - OFFICE

SINGLE WIDE TRAILER - LAB

SINGLE WIDE TRAILER - LAB

SINGLE WIDE TRAILER - OFFICE

SINGLE WIDE TRAILER - LAB
FAC 480

8LO 482

BLD 485

BLD 486

BLD 489

TRL 906

TRL 907

TRL 908A

TRL 90BB

TRL 909

TRL 910

TRL $911 \mathrm{~A}$

TRL 9118

TRL $911 \mathrm{C}$

TRL $911 E$

TRL $911 F$

TRL 9116

TRL 912

TRL $914 \mathrm{~A}$

TRL 915

TRL 916

TRL 917

TRL 918

TRL $918 A$

TRL $918 B$

TRL 950

TRL 951

TRL 952

TRL 971

TRL 982

TRL 985

TRL 986

TRL 988

TRL 991

TRL 992

TRL 993

TRL 994

TRL 995 


\section{APPENDIX A \\ WIPP LAYOUT DIAGRAMS \\ Underground Facilities}

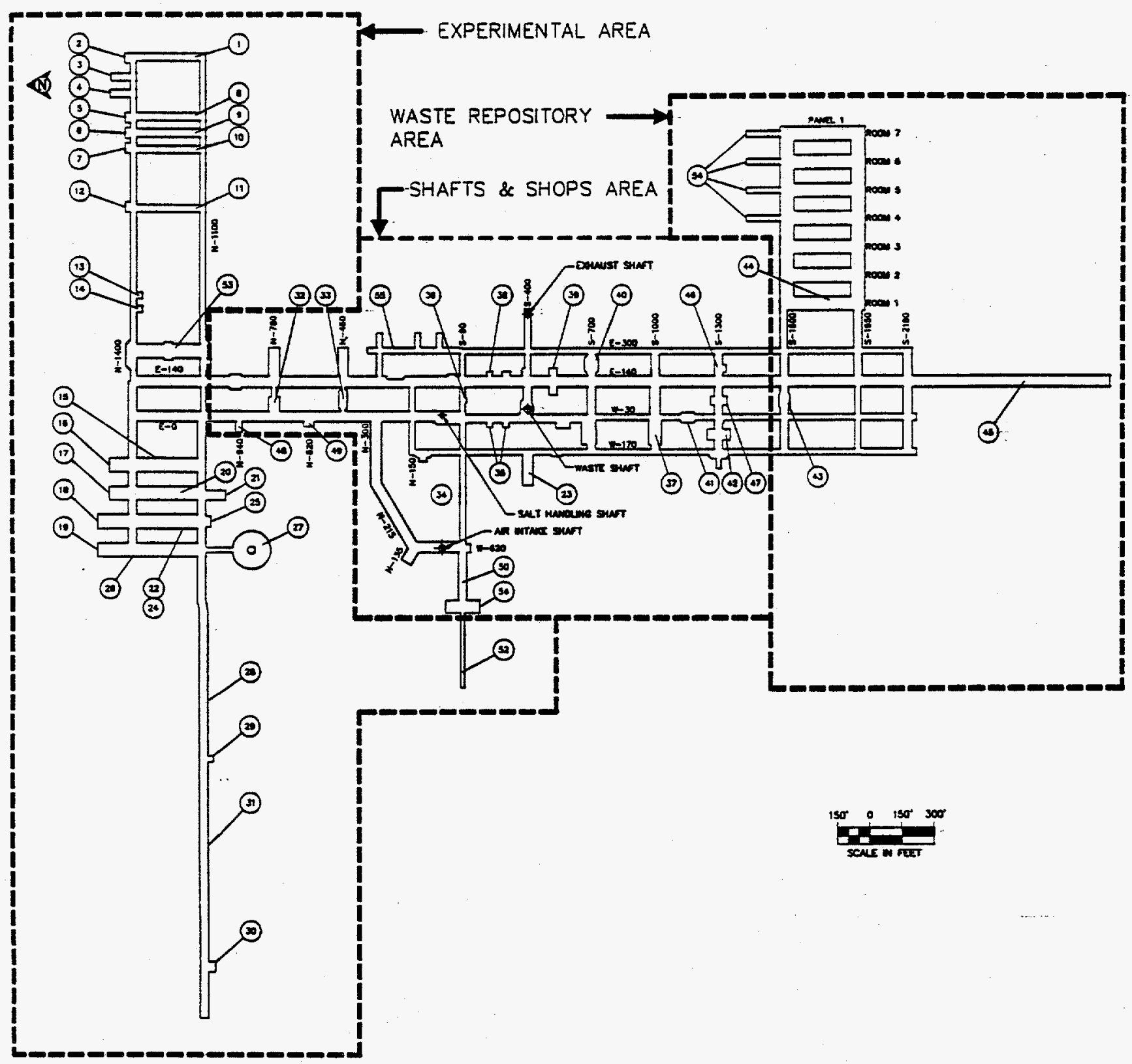




\section{APPENDIX A \\ WIPP LAYOUT DIAGRAMS Underground Facilities Legend}

\section{UNDERGBQUND FACHLTIES}

ROOM D: ROCK MECHANICS STATION FOR SNL ERINE INFLOW AND HUMIOIY SCALEUP

1-7: ROCK MECHANICS STATION AND PLUCGING AND SEALING EXPERIMENTS

$c-i$

$\mathrm{C}-2$ :

1-6; INSTRUMENT SHED FOR ROOM A-J

1-5; INSTRUMENT SHED FOR ROOM A-2

1-4: INSTRUMENT SHEO FOR ROOM A-1

ROOM A-3: THERMAL STRUCTURE INTERACTIONS. BASELINE

ROON A-2: THERMAL STRUCTURAL, INTERACTIONS, BASELINE

. ROOM A-i: THERMAL STRUCTURAL INTERACTONS. BASELINE WASTE PACKAGE PERFORMANCE. BASELINE ROOM B: THERMAL STRUCTURAL INTERACTONS. OVERTEST WASTE PACXAGE PERFORUANCE OVERTEST

1-3: INSTRUMENT SHED FOR ROON B

3. ELECTRICAL SUESTATION NO. 2A

4. SWITCH STATION

5. ROOM 1: (EXPERIMENTAL)

6. L-1: PLUGGING AND SCALING TEST SERIES D AND INSTRUMENT SHEO

7. L-2; PLUGGiNG AND SEALINC TEST SERIES D

8. L-3; PLUGGing AND SEALUNG TEST SERIES E

19. L-4: PLUGGING AND SEALING TEST SERES $F$

20. ROOM 2: (EXPERINENTAL)

29. ROOM J: MATERIALS INTERFACE INTERACTIONS TEST

22. ROOM 3: (EXPERIMENTAL)

23. CORE STORAGE

24. ROOM T: CH/TRU DRUM CRUSHING RH/TRU SIMULATEO HEATERS

25. 1-2 INSTRUMENT SHED FOR ROOM H. J. \& $T$

26. ROOM 4: SALT BLOCK FABRICATION

27. ROOM H: THERMAL STRUCTURAL INTERACTONS, AXISMMTTRICAL PILLAR

28. ENTRY TO ROOM G

29. ELECTRICAL SUESTATION NO. 28
30. 1-1: INSTRUMENT SHED FOR ROOM G

If. ROOM G: THERMAL STRUCTURAL INTERAPTIONS. REFERENCE

32. MINING OPERATIONS FAERICATION SHOP

33. UNDERGROUND ACCESS WAY

34. MINING OPERATIONS FUEL STATION

35. EMERGENCY VEHICLE PARKING

36. ELECTRICAL SUBSTATON NO. I \& SWITCH STATION

37. MINE OPERATIONS OFFICE ANO LUNCH ROOM

38. ELECTRICAL SWITCH STATION

39. WASTE HANOLING VEHICLE PARKING

40. RH DEMO AREA

41. FLOW REVERSING VENTILATION BOOSTER FANS

42. UNDERGROUND SHOP

43. WASH BAY

44. PANEL 1, ROON 1. UNDERGROUND STORMCE AREA

45. SPDV EXPLORATION DRIFT-SOUTH

46. WASTE HANDUNG DIESEL FUEL STATON

47. UNOERGROUND SHOPS. PARTS. LUNCHROOM MNO OFFCE

46. SEAL TEST ALCOVE

49. UNOERGROUND SERVICE, TOOL ANO STORMGE SHED

5O. CIRCUUAR ROOM ACCESS ORIFT

51. CIRCUUAR ROOM INSTRUMENT AREA

52. ROOM O; CIRCULAR ROOM

53. SNL SHOPS AREA

54. ENTRIES FOR TEST ALCOVES

55. UNOERGROUND SHOP

NOTE

1. EXISTING CONOTIONS AS OF SEPTEMBER 30. 1994 
APPENDIX B ACRONYMSIABBREVIATIONS

CAMP Capital Asset Management Process

CAS Condition Assessment Survey

CAIS Condition Assessment Information System

CAIP Capital Asset Implementation Plan

CHAMPS Computerized History and Maintenance Planning System

DOE Department of Energy

FTE Full Time Equivalent

FU Functional Unit

FUBS Functional Unit Breakdown Structure

FUDS Functional Unit:Data Sheets

FY Fiscal Year

RPIS Real Property Inventory System

WID Waste Isolation Division

WIPP Waste Isolation Pilot Plant

WBS Work Breakdown Structure 


\section{APPENDIX C GLOSSARY OF TERMS}

Capital Asset - A tangible product of value, generally property, or equipment which has an anticipated service life of two years or more and a cost equal to or greater than $\$ 5000.00$.

Capital Asset Management Process (CAMP) - The standardized, auditable process for determining condition, forecasting life cycle events, and identifying planning and prioritizing capital asset needs in light of meeting mission requirements.

Condition Assessment Survey(CAS) - A periodic inspection of capital assets using universally accepted standards and methods. A CAS results in a determination of the current condition of capital assets, the estimated time to failure, and the estimated cost to correct the identified deficiencies. CAS provides a consistent assessment of capital assets for planning purposes based on actual conditions.

Condition Assessment Information System(CAIS) - A personal computer based database system operating under the UNIX operating system and the ORACLE relational database software. CAIS uses state-of-the-art technology to streamline the CAS inspection process, eliminating handwritten forms, electronically transferring inspection deficiency information to the database, and preparing summary reports for use in preparing comprehensive and standardized CAMP Reports.

Functional Unit(FU) - A logical and systematic group of capital assets with similar lifecycles is necessary to support the site's mission. The FUs shall be capable of being audited in terms of mission requirements and performance standards.

Functional Unit Breakdown Structure(FUBS) - A method for listing and identifying the site's FUs and establishing a framework for managing capital assets by FU. The FUBS provides a logical hierarchical series structure of FUs that includes all the site's capital assets for specifying, summarizing, and justifying capital asset funding needs.

Functional Unit Data Sheets(FUDS) - The FUDS is a summary document containing the relevant data for a significant project in the life of a particular FU.

Life Cycle Plan(LCP) - A LCP shows forecasted major activities in the life of an asset through final disposition. The plan documents the history of the FU and forecasts durations, relationships, and impact on life expectancy. The plan also describes maintenance practices and costs.

Maintenance - Day-to-day work that is required to maintain and preserve facility and capital equipment in a condition suitable for it to be used for its designated purpose and includes preventive, predictive, and corrective maintenance.

Project - A project is the selected alternative listed and prioritized in the CAMP Report 
for meeting a capital asset requirement. A project may involve a single capital asset or an entire functional units. CAMP projects include significant maintenance, General Plant Projects, Line Item projects; or significant capital expenditures. 


\section{CAMP ORGANIZATION CHART}

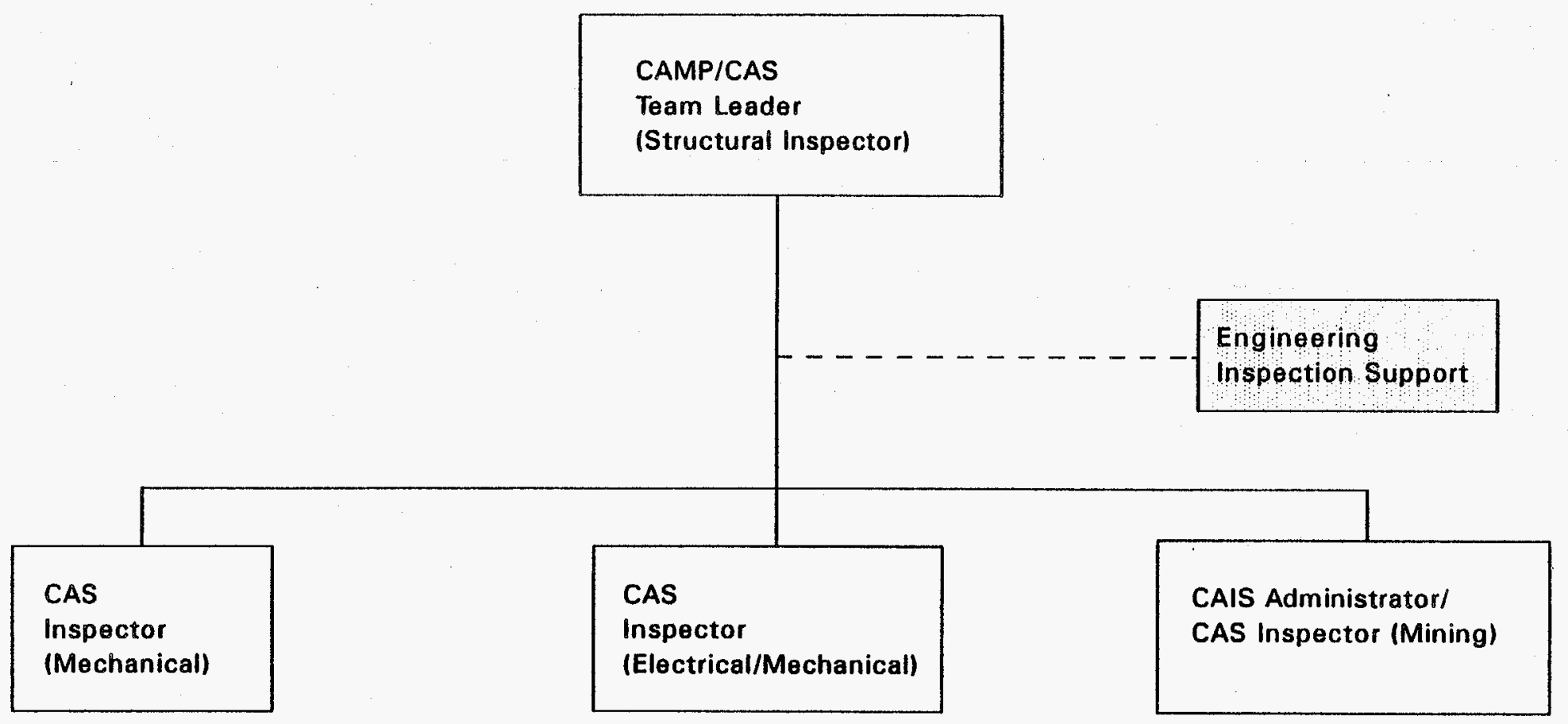


APPENDIX E

INSPECTION SCHEDULE

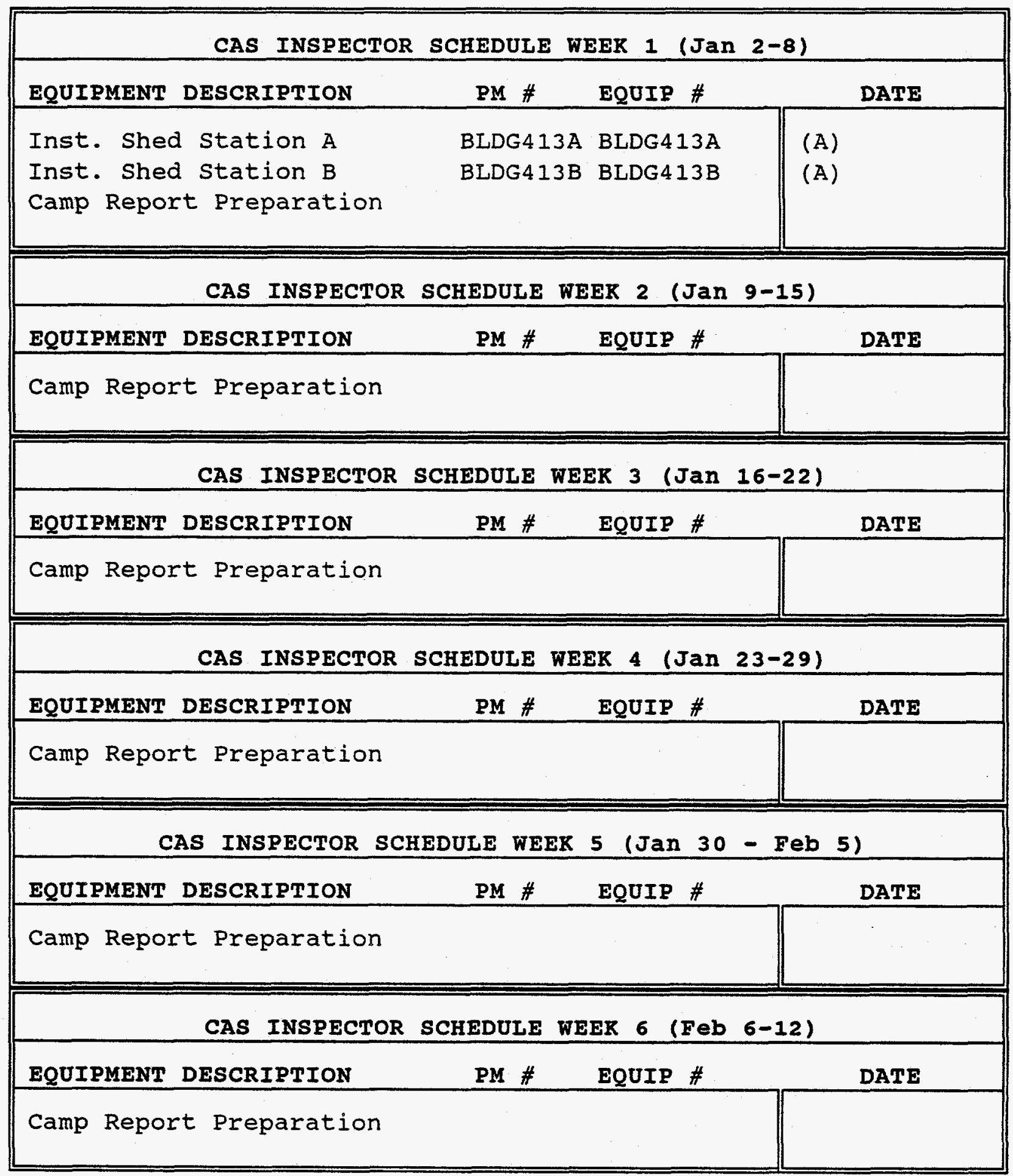


APPENDIXE

INSPECTION SCHEDULE

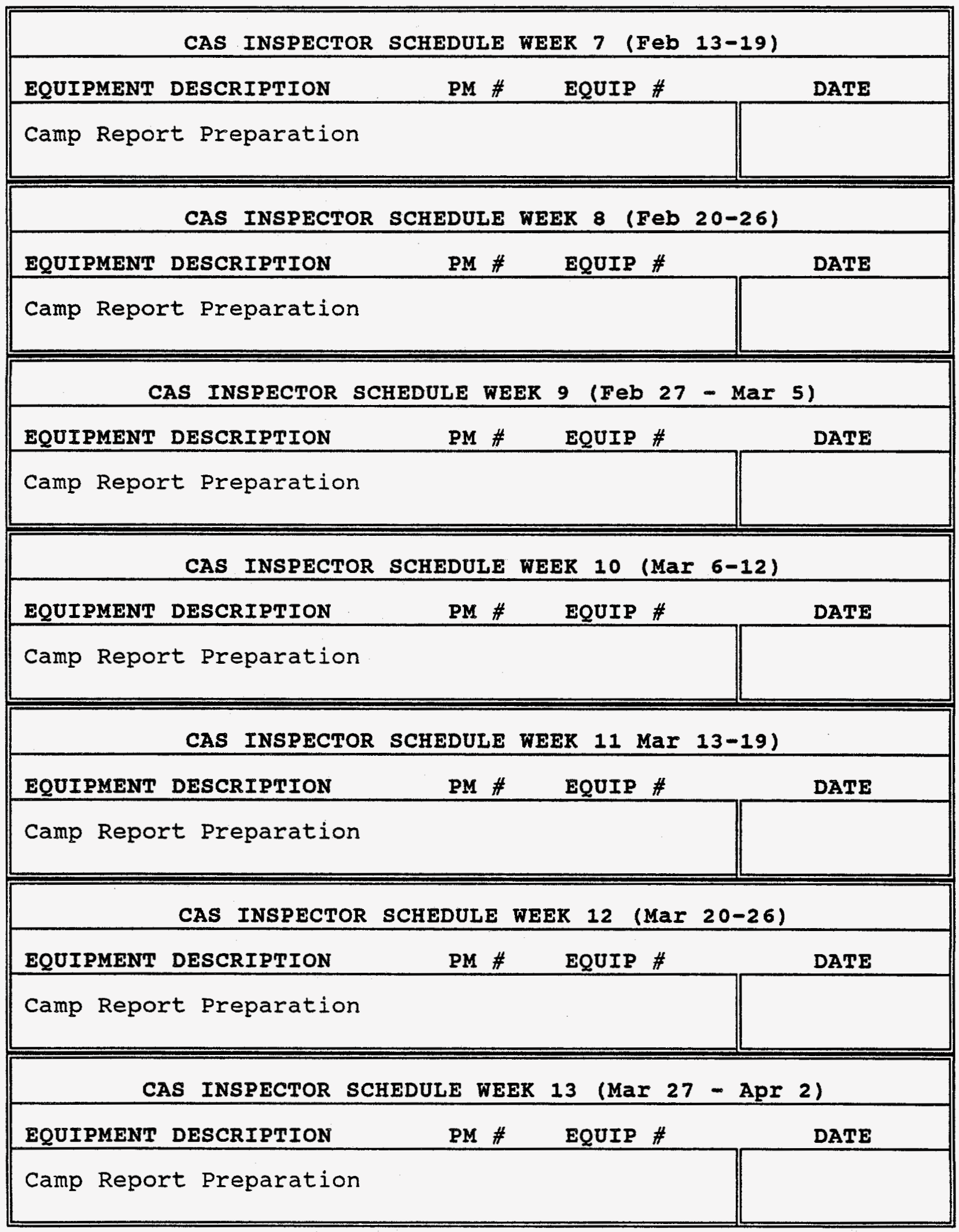


APPENDIX E

INSPECTION SCHEDULE

\begin{tabular}{|c|c|c|}
\hline CAS INSPECTOR & SCHEDULE WEEK 14 (Apr & $3-9)$ \\
\hline EQUIPMENT DESCRIPTION & EQUIP \# & DATE \\
\hline \multicolumn{3}{|l|}{ Camp Report Preparation } \\
\hline CAS INSPECTOR & SCHEDULE WEER 15 (Apr : & $10-16)$ \\
\hline EQUIPMENT DESCRIPTION & EQUIP \# & DATE \\
\hline \multicolumn{3}{|l|}{ Camp Report Preparation } \\
\hline \multicolumn{3}{|c|}{ CAS INSPECTOR SCHEDULE WEEK 16 (Apr 17-23) } \\
\hline EQUIPMENT DESCRIPTION & EQUIP \# & DATE \\
\hline Fuel storage Tanks & FAC480 & (A) \\
\hline \multicolumn{3}{|c|}{ CAS INSPECTOR SCHEDULE WEEK 17 (APr 24-30) } \\
\hline \multicolumn{2}{|c|}{ EQUIPMENT DESCRIPTION $\quad$ PM \# $\quad$ EQUIP \# } & DATE \\
\hline \multirow{3}{*}{$\begin{array}{l}\text { Salt Hoist House } \\
\text { Monitoring Station A } \\
\text { Monitoring Station B }\end{array}$} & \multirow{3}{*}{$\begin{array}{l}\text { BLDG384 } \\
\text { FAC364 } \\
\text { FAC } 365 \\
\end{array}$} & \multirow{3}{*}{$\begin{array}{l}\text { (A) } \\
(A) \\
(A) \\
\end{array}$} \\
\hline & & \\
\hline & & \\
\hline \multicolumn{3}{|c|}{ CAS INSPECTOR SCHEDULE WEEK 18 (MaY 1-7) } \\
\hline EQUIPMENT DESCRIPTION & EQUIP \# & DATE \\
\hline Roof Exhaust Fan & $45 B 409$ & (A) \\
\hline CAS INSPECTOR & SCHEDULE WEER 19 (MaY & $8-14)$ \\
\hline EQUIPMENT DESCRIPTION & EQUIP \# & DATE \\
\hline SPS Utility Substation & FAC252 & (A) \\
\hline $13.8 \mathrm{kV}$ Switchgear & FAC253 FAC253 & (A) \\
\hline Area Substation 1 & FAC254.1 FAC254.1 & (A) \\
\hline Area Substation 2 & FAC2 54.2 FAC254.2 & (A) \\
\hline Area Substation 3 & FAC254.3 FAC254.3 & (A) \\
\hline
\end{tabular}


APPENDIX E

INSPECTION SCHEDULE

\begin{tabular}{|c|c|c|}
\hline CAS INSPECTOR & SCHEDULE WEEK 20 (MaY & $15-21)$ \\
\hline EQUIPMENT DESCRIPTION & EQUIP \# & DATE \\
\hline Area substation 4 & FAC2 24.4 FAC254.4 & (A) \\
\hline Area substation 5 & $\mathrm{FAC} 254.5 \quad F A C 254.5$ & (A) \\
\hline Area substation 6 & FAC254.6 FAC254.6 & (A) \\
\hline Area Substation 7 & FAC254.7 FAC254.7 & (A) \\
\hline Area Substation 8 & FAC254.8 FAC254.8 & (A) \\
\hline CAS INSPECTOR & SCHEDULE WEEK 21 (MaY & $22-28)$ \\
\hline EQUIPMENT DESCRIPTION & EQUIP \# & DATE \\
\hline 6 Ton Electric Forklift & $74 \mathrm{HO1OB}$ & (M) \\
\hline Backup Generator 1 & FAC255.1 FAC255.1 & (A) \\
\hline Backup Generator 2 & FAC2 55.2 FAC255.2 & (A) \\
\hline
\end{tabular}


APPENDIX E

INSPECTION SCHEDULE

\begin{tabular}{|c|c|c|c|}
\hline CAS INSPECTOR & SCHEDULE WEER & (May 29 & - Jun 4I \\
\hline EQUIPMENT DESCRIPTION & PM \# & EQUIP \# & DATE \\
\hline Trailer 906 & TRLR906 & TRLR906 & $(A)$ \\
\hline Trailer 908A & TRLR908A & TRLR908A & (A) \\
\hline Trailer 908B & TRLR908B & TRLR908B & (A) \\
\hline Trailer 909 & TRLR909 & TRLR909 & (A) \\
\hline Trailer 910 & TRLR910 & TRLR910 & (A) \\
\hline Trailer $911 \mathrm{~A}$ & TRLR911A & TRLR911A & (A) \\
\hline Trailer 911B & TRLR911B & TRLR911B & (A) \\
\hline Trailer $911 \mathrm{C}$ & TRLR911C & TRLR911B & (A) \\
\hline Trailer $911 \mathrm{E}$ & TRLR911E & TRLR911E & $(A)$ \\
\hline Trailer $911 \mathrm{G}$ & TRLR911G & TRLR9 11G & (A) \\
\hline Trailer 912 & TRLR9 12 & TRLR9 12 & (A) \\
\hline Trailer 916 & TRLR9 16 & TRLR9 16 & (A) \\
\hline Trailer 918 & TRLR9 18 & TRLR9 18 & (A) \\
\hline Trailer 918A & TRLR918A & TRLR9 18A & (A) \\
\hline Trailer 918B & TRLR918B & TRLR9 18B & (A) \\
\hline Trailer 950 & TRLR950 & TRLR950 & (A) \\
\hline Trailer 951 & TRLR951 & TRLR951 & (A) \\
\hline Trailer 971 & TRLR971 & TRLR971 & (A) \\
\hline Trailer 982 & TRLR982 & TRLR982 & (A) \\
\hline Trailer 985 & TRLR985 & TRLR985 & (A) \\
\hline Trailer 986 & TRLR986 & TRLR986 & (A) \\
\hline Trailer 988 & TRLR988 & TRLR988 & (A) \\
\hline Trailer 991 & TRLR991 & TRLR991 & (A) \\
\hline Trailer 992 & TRLR992 & TRLR992 & (A) \\
\hline Trailer 993 & TRLR993 & TRLR993 & (A) \\
\hline Trailer 994 & TRLR994 & TRLR994 & (A) \\
\hline Trailer 995 & TRLR995 & TRLR995 & (A) \\
\hline Met Labs (SNL,WID) & BLDG 470 & BLDG 470 & (A) \\
\hline NE Met Tower & BLDG 472 & BLDG 472 & (A) \\
\hline
\end{tabular}


APPENDIX E

INSPECTION SCHEDULE

\begin{tabular}{|c|c|c|}
\hline EQUIPMENT DESCRIPTION & EQUIP \# & DATE \\
\hline $\begin{array}{l}\text { Hazardous Storage BLDG } \\
\text { Sewage Lagoon } \\
\text { Hoisting Systems -- Norberg } \\
\text { Hoisting will perform their } \\
\text { of the site hoists. We wil } \\
\text { this inspection. }\end{array}$ & $\begin{array}{l}\text { BLDG474 BLDG474 } \\
\text { FAC258 FAC258 } \\
\text { Manufacturer of } \\
\text { annual inspection } \\
\text { participate in }\end{array}$ & $\begin{array}{l}\text { (A) } \\
\text { (A) }\end{array}$ \\
\hline \multicolumn{3}{|c|}{ CAS INSPECTOR SCHEDULE WEEK 24 (JUn 12-18) } \\
\hline EQUIPMENT DESCRIPTION & EQUIP \# & DATE \\
\hline $\begin{array}{l}\text { Firetruck Surface GMC } \\
\text { U/G Exhaust Fan } 250 \text { HP } \\
\text { H. Conveyance Loading Cart } \\
\text { Gaurd \& Security BLDG }\end{array}$ & $\begin{array}{ll}75 Q 003 & 750003 \\
041043 & 41 \mathrm{~B} 860 \mathrm{~B} \\
41 \mathrm{H} 018 & 41 \mathrm{H} 018 \\
\text { BLDG458 } & \text { BLDG458 }\end{array}$ & $\begin{array}{l}\text { (Q) } \\
\text { (Q) } \\
\text { (A) } \\
\text { (A) }\end{array}$ \\
\hline \multicolumn{3}{|c|}{ CAS INSPECTOR SCHEDULE WEEK 25 (JUn 19-25) } \\
\hline EQUIPMENT DESCRIPTION & PM \# EQUIP \# & DATE \\
\hline $\begin{array}{l}\text { U/G Exhaust Fan } 250 \mathrm{HP} \\
\text { Core Storage BLDG } \\
459 \text { Annex } \\
\text { North Access Rd } \\
\end{array}$ & $\begin{array}{ll}041042 & 41 B 860 A \\
\text { BLDG459 } & \text { BLDG } 459 \\
\text { BLDG459A } & \text { BLDG459A } \\
\text { FAC200 } & \text { FAC200 } \\
\end{array}$ & $\begin{array}{l}\text { (Q) } \\
(\mathrm{A}) \\
(\mathrm{A}) \\
(\mathrm{A})\end{array}$ \\
\hline CAS INSPECTOR SCHED & LE WEEK 26 (JUN 26 & ruI 2) \\
\hline EQUIPMENT DESCRIPTION & EQUIP \# & DATE \\
\hline $\begin{array}{l}\text { Rescue Truck } \\
\text { Air Compressor A \& B } \\
\text { Condor } 66 \text { Aerial Platform }\end{array}$ & $\begin{array}{ll}750004 \mathrm{~A} & 750004 \mathrm{~A} \\
045073 & 45 \mathrm{G} 400 \\
74 \mathrm{~W} 040 & 74 \mathrm{~W} 040\end{array}$ & $\begin{array}{l}\text { (A) } \\
(Q) \\
(\mathrm{M})\end{array}$ \\
\hline
\end{tabular}


APPENDIXE

INSPECTION SCHEDULE

\begin{tabular}{|c|c|c|c|}
\hline EQUIPMENT DESCRIPTION & PM \# & EQUIP \# & DATE \\
\hline $\begin{array}{l}\text { Mechanical Overhead Door } \\
\text { (Outside) } \\
\text { Water Chiller } \\
\text { Water Chiller } \\
\text { Chilled Water Pump } \\
\text { Chilled Water Pump } \\
\text { H. M. Shield Door 155 } \\
\text { Overhead Door (CH Side) } \\
\text { Gatehouse }\end{array}$ & $\begin{array}{l}041087 \\
041088 \\
041085 \\
041086 \\
\text { O41108 } \\
\text { DOOR133 } \\
\text { BLDG } 475\end{array}$ & $\begin{array}{l}41 \mathrm{~B} 890 \mathrm{~A} \\
41 \mathrm{~B} 890 \mathrm{~B} \\
41 \mathrm{~B} 891 \mathrm{~A} \\
41 \mathrm{~B} 891 \mathrm{~B} \\
41 \mathrm{~N} 014 \\
\text { DOOR133 } \\
\text { BLDG475 }\end{array}$ & $\begin{array}{l}\text { (Q) } \\
\text { (S) } \\
\text { (S) } \\
\text { (S) } \\
\text { (S) } \\
\text { (A) } \\
\text { (A) }\end{array}$ \\
\hline \multicolumn{4}{|c|}{ CAS INSPECTOR SCHEDULE WEEK 28 (JU) 10-16) } \\
\hline EQUIPMENT DESCRIPTION & PM \# & EQUIP \# & DATE \\
\hline $\begin{array}{l}\text { H. Mech. Overhead Door } \\
\text { H. Mech. Overhead Door } \\
\text { H. Elec. Clark Forklift } \\
\text { (CH Bay) } \\
\text { Armory }\end{array}$ & $\begin{array}{l}\text { DOOR140 } \\
\text { DOOR159 } \\
041015 \\
\text { BLDG } 473\end{array}$ & $\begin{array}{l}\text { DOOR140 } \\
\text { DOOR159 } \\
41 \mathrm{H} 009 \\
\text { BLDG } 473\end{array}$ & $\begin{array}{l}\text { (Q) } \\
(Q) \\
(Q) \\
\text { (A) }\end{array}$ \\
\hline \multicolumn{4}{|c|}{ CAS INSPECTOR SCHEDULE WEEK 29 (JUI 17-23) } \\
\hline EQUIPMENT DESCRIPTION & PM \# & EQUIP \# & DATE \\
\hline $\begin{array}{l}\text { Overhead Door (Outside) } \\
\text { Overhead Door (Outside) } \\
\text { Overhead Door (Outside) } \\
\text { Overhead Door (CH Side) } \\
\text { H. M. Shield Door } 145 \\
\text { RH HI Bay } \\
\text { Air Handling Unit } \\
\text { Air Compressor A \& B } \\
\text { Toyota Diesel } 6 \text { Ton Forklift }\end{array}$ & $\begin{array}{l}\text { DOOR101 } \\
\text { DOOR119 } \\
\text { DOOR124 } \\
\text { DOOR131 } \\
\text { O41108 }\end{array}$ & $\begin{array}{l}\text { DOOR101 } \\
\text { DOOR119 } \\
\text { DOOR124 } \\
\text { DOOR131 } \\
41 \text { N016 }\end{array}$ & $\begin{array}{l}\text { (Q) } \\
\text { (Q) } \\
\text { (Q) } \\
(A) \\
\text { (Q) } \\
\text { (S) } \\
\text { (Q) } \\
\text { (A) }\end{array}$ \\
\hline
\end{tabular}


APPENDIX E INSPECTION SCHEDULE

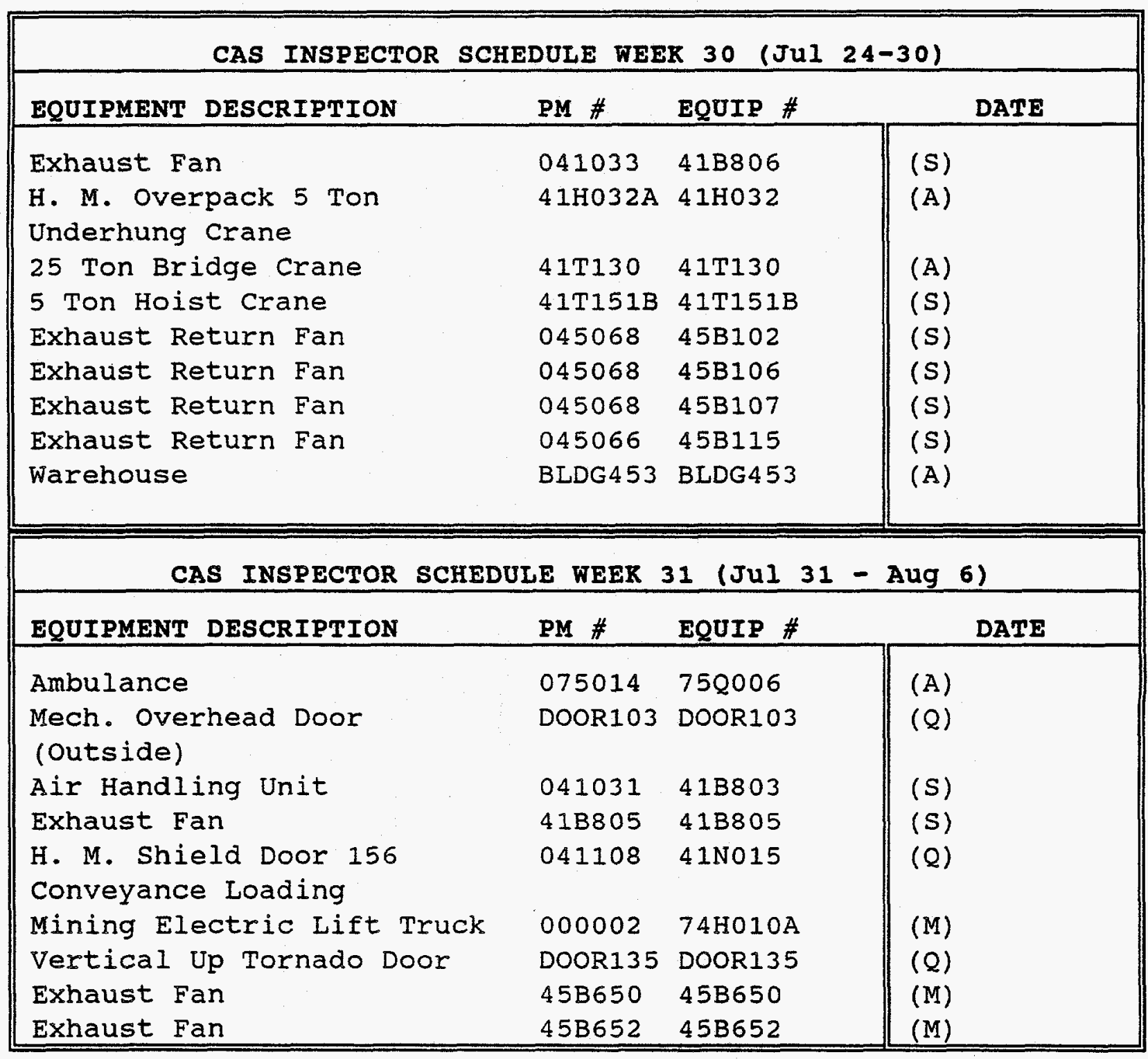


APPENDIX E

INSPECTION SCHEDULE

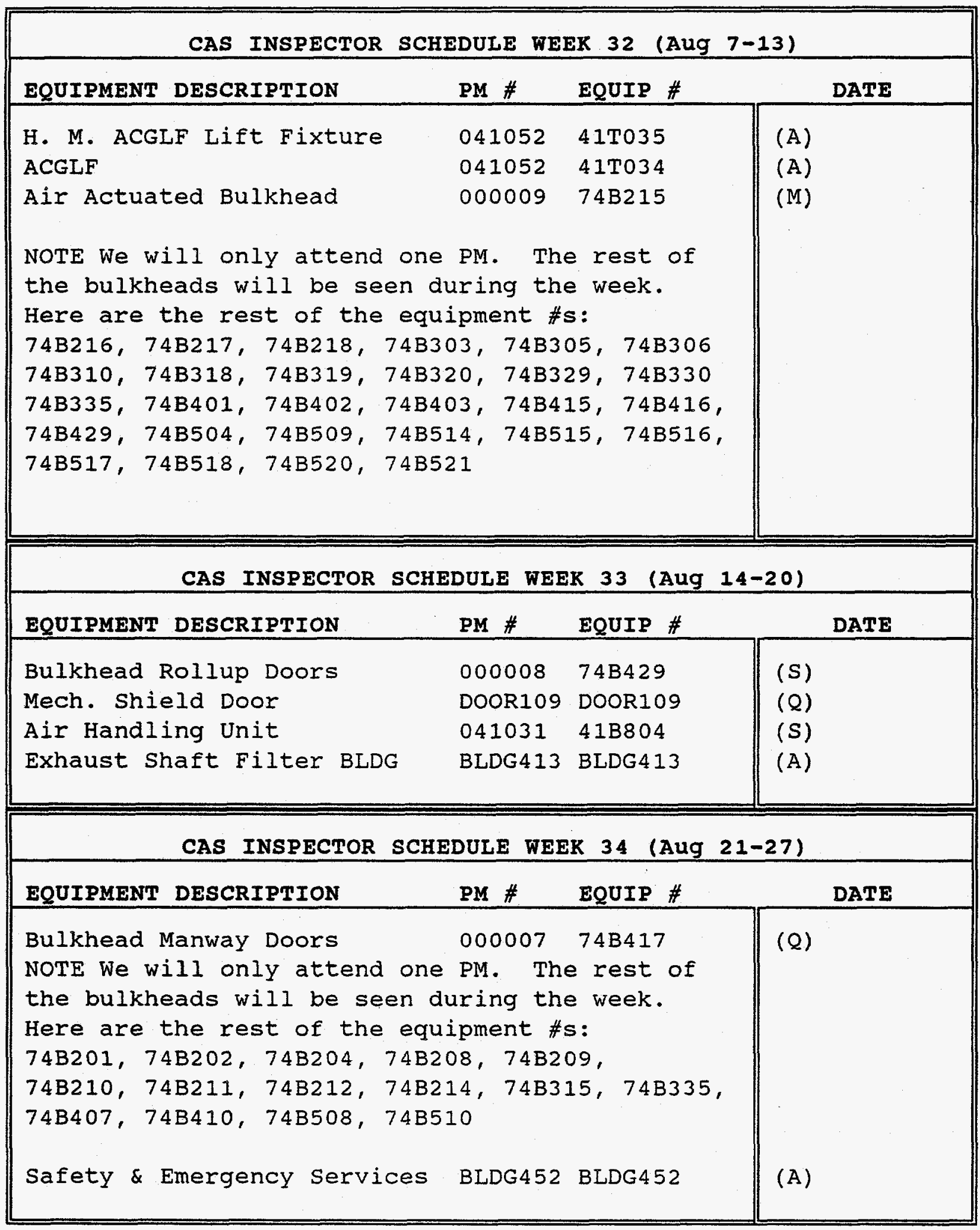


APPENDIX E

INSPECTION SCHEDULE

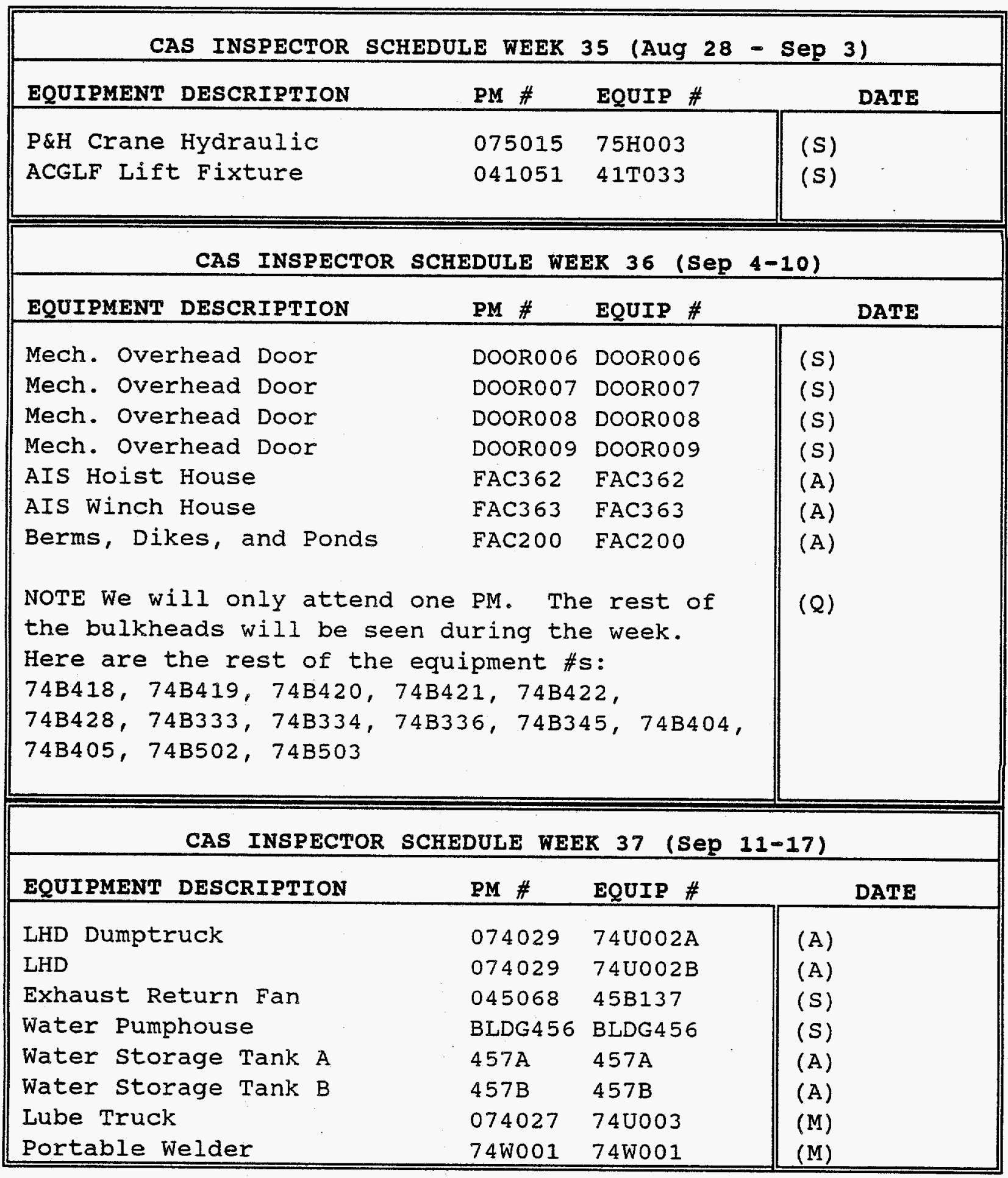


APPENDIX E

INSPECTION SCHEDULE

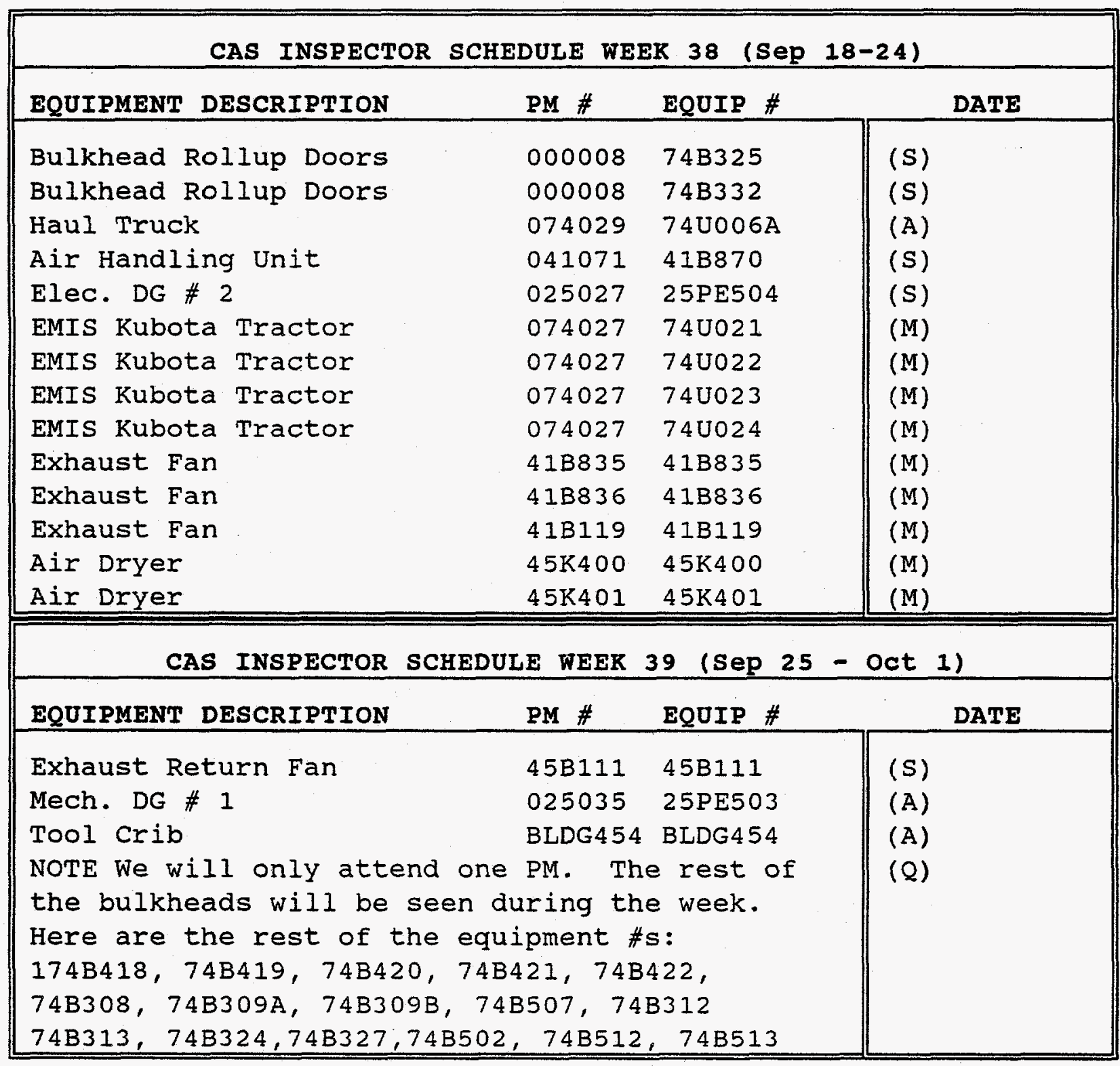


APPENDIX E

INSPECTION SCHEDULE

CAS INSPECTOR SCHEDULE WEEK 40 (OCt 2-8)

\begin{tabular}{|ll|l||}
\hline EQUIPMENT DESCRIPTION & PM \# & EQUIP \# \\
\hline U/G Exhaust Fan 650 HP & 041025 41B700A & (S) \\
Hoisting Services & FAC384A FAC384A & $(\mathrm{A})$ \\
NOTE We will only attend one PM. The rest of & $(\mathrm{Q})$ \\
the bulkheads will be seen during the week. & \\
Here are the rest of the equipment \#S: \\
74B311, 74B317, 74B323, 74B326, 74B408, \\
74B413
\end{tabular}

CAS INSPECTOR SCHEDULE WEER 41 (Oct 9-15)

\begin{tabular}{|c|c|c|c|}
\hline EQUIPMENT DESCRIPTION & PM \# & EQUIP \# & DATE \\
\hline EMIS Lift Truck & 074027 & $52 \mathrm{H} 007 \mathrm{~B}$ & (A) \\
\hline HL Dump Truck & 074029 & 740039 & (A) \\
\hline Haul Truck & 074029 & $74 \mathrm{U} 006 \mathrm{~B}$ & (A) \\
\hline Underground Ambulance & $740011 S$ & 740011 & (S) \\
\hline H. Elec. ACGLF Lift Fixture & 041051 & $41 \mathrm{~T} 032$ & (S) \\
\hline Getman Haul Truck & 074027 & 74 UE0 44 & (M) \\
\hline 6 Ton Electrical Forklift & $74 \mathrm{HO} 0 \mathrm{OB}$ & $74 \mathrm{HO} 10 \mathrm{~B}$ & (M) \\
\hline 41 Ton Forklift & $52 \mathrm{H} 005 \mathrm{~A}$ & $52 \mathrm{H} 005 \mathrm{~A}$ & (A) \\
\hline TRUPACT Maintenance Fac & BLDG4 12 & BLDG4 12 & (A) \\
\hline Transporter & $52 \mathrm{H} 008 \mathrm{~A}$ & $52 \mathrm{HOOOA}$ & (A) \\
\hline Transporter & $52 \mathrm{HOO} B \mathrm{~B}$ & $52 \mathrm{H} 008 \mathrm{~B}$ & (A) \\
\hline Dosco Roadheader Miner & 74 UM0 66 & $74 \mathrm{UMO} 066$ & (M) \\
\hline \multicolumn{4}{|c|}{ CAS INSPECTOR SCHEDULE WEEK 42 (Oct 16-22) } \\
\hline EQUIPMENT DESCRIPTION & PM \# & EQUIP \# & DATE \\
\hline Air Dryer & 041074 & $41 \mathrm{~K} 001$ & (S) \\
\hline EMIS Fire Rescue Truck & 074027 & $74 Q 014$ & (M) \\
\hline Maintenance shop & BLDG 455 & BLDG 455 & (A) \\
\hline Atlas Rock Bolter & 074027 & $74 \mathrm{U111}$ & (M) \\
\hline Getman Haul Truck & 074027 & 74 UE0 43 & (M) \\
\hline Supply Truck With Crane & 074027 & 74 UE0 60 & (M) \\
\hline 12 Ton Haul Truck & $74 \mathrm{U} 006 \mathrm{~B}$ & $74 \mathrm{U} 006 \mathrm{~B}$ & (M) \\
\hline
\end{tabular}


APPENDIXE

INSPECTION SCHEDULE

\begin{tabular}{|c|c|c|c|c|}
\hline \multicolumn{3}{|c|}{ CAS INSPECTOR SCHEDULE WEER 43 loct } & $23-29)$ & \multirow[b]{2}{*}{ DATE } \\
\hline EQUIPMENT DESCRIPTION & PM \# & EQUIP \# & & \\
\hline Haul Truck & 074029 & $74 \mathrm{U} 006 \mathrm{C}$ & (A) & \\
\hline U/G Exhaust Fan 650 HP & 041027 & $41 B 700 B$ & (S) & \\
\hline H. M. 13 Ton Elec. Forklift & $41 \mathrm{HO} 12 \mathrm{~A}$ & $41 \mathrm{H} 012 \mathrm{~A}$ & (S) & \\
\hline Marietta Miner & & $74 \mathrm{U} 030$ & (M) & \\
\hline Getman Haul Truck & 074027 & $74 \mathrm{UEO} 42$ & $(\mathrm{M})$ & \\
\hline Roof Bolter & $74 \mathrm{UMO} 57 \mathrm{M}$ & 174 UM057 & (M) & \\
\hline 20 Ton Diesel Forklift & $52 \mathrm{H} 125$ & $52 \mathrm{H} 125$ & (M) & \\
\hline Engineering Bldg & BLDG 486 & BIDG 486 & (A) & \\
\hline Getman Lift Truck & $74 \mathrm{U} 008$ & 740008 & $(\mathrm{M})$ & \\
\hline CAS INSPECTOR SCHEDL & $\triangle E$ WEER 4 & 14 loct 30 & - Nov & 5) \\
\hline EQUIPMENT DESCRIPTION & PM \# & EQUIP \# & & DATE \\
\hline NDE Lift Truck & NDE & $74 \mathrm{HO} 3$ & (A) & \\
\hline Air Dryer & $41 \mathrm{~K} 002$ & $41 \mathrm{~K} 002$ & (Q) & \\
\hline Support BLDG & BIDG 451 & BLDG451 & (A) & \\
\hline EMIS Kubota Tractor & 074027 & 740020 & $(\mathrm{M})$ & \\
\hline Forklift & $52 \mathrm{H} 126$ & $52 \mathrm{H} 126$ & $(M)$ & \\
\hline Getman Lift Truck & $74 \mathrm{U} 114$ & $74 U 114$ & $(\mathrm{M})$ & \\
\hline Fletcher Scaler & $74 U 115$ & $74 U 115$ & (M) & \\
\hline Diesel Powered Generator & 74UE067 & 74 UE0 67 & (M) & \\
\hline 6 Ton Diesel Forklift & $52 \mathrm{H} 007 \mathrm{~A}$ & $52 \mathrm{H} 007 \mathrm{~A}$ & $(\mathrm{M})$ & \\
\hline CAS INSPECTOR SCI & EDULE WEE & ER 45 (Nov & $6-12)$ & \\
\hline EQUIPMENT DESCRIPTION & PM \# & EQUIP \# & & DATE \\
\hline Sullair Compressor BIDG & BLDG4 85 & BLDG 485 & (A) & \\
\hline Miller Welder Portable & 074027 & $74 W 001$ & (M) & \\
\hline Electric Shop & BLDG 482 & BLDG 482 & (A) & \\
\hline Skid Str Mini Scaler & 074027 & $74 \cup 038$ & $(\mathrm{M})$ & \\
\hline Electric Scissor Lift & $74 \mathrm{U} 071$ & $74 U 071$ & $(\mathrm{M})$ & \\
\hline LHD & $74 U 105$ & $74 U 105$ & $(\mathrm{M})$ & \\
\hline LHD & $74 \mathrm{U} 117$ & $74 \mathrm{U} 117$ & $(\mathrm{M})$ & \\
\hline
\end{tabular}


APPENDIX E INSPECTION SCHEDULE

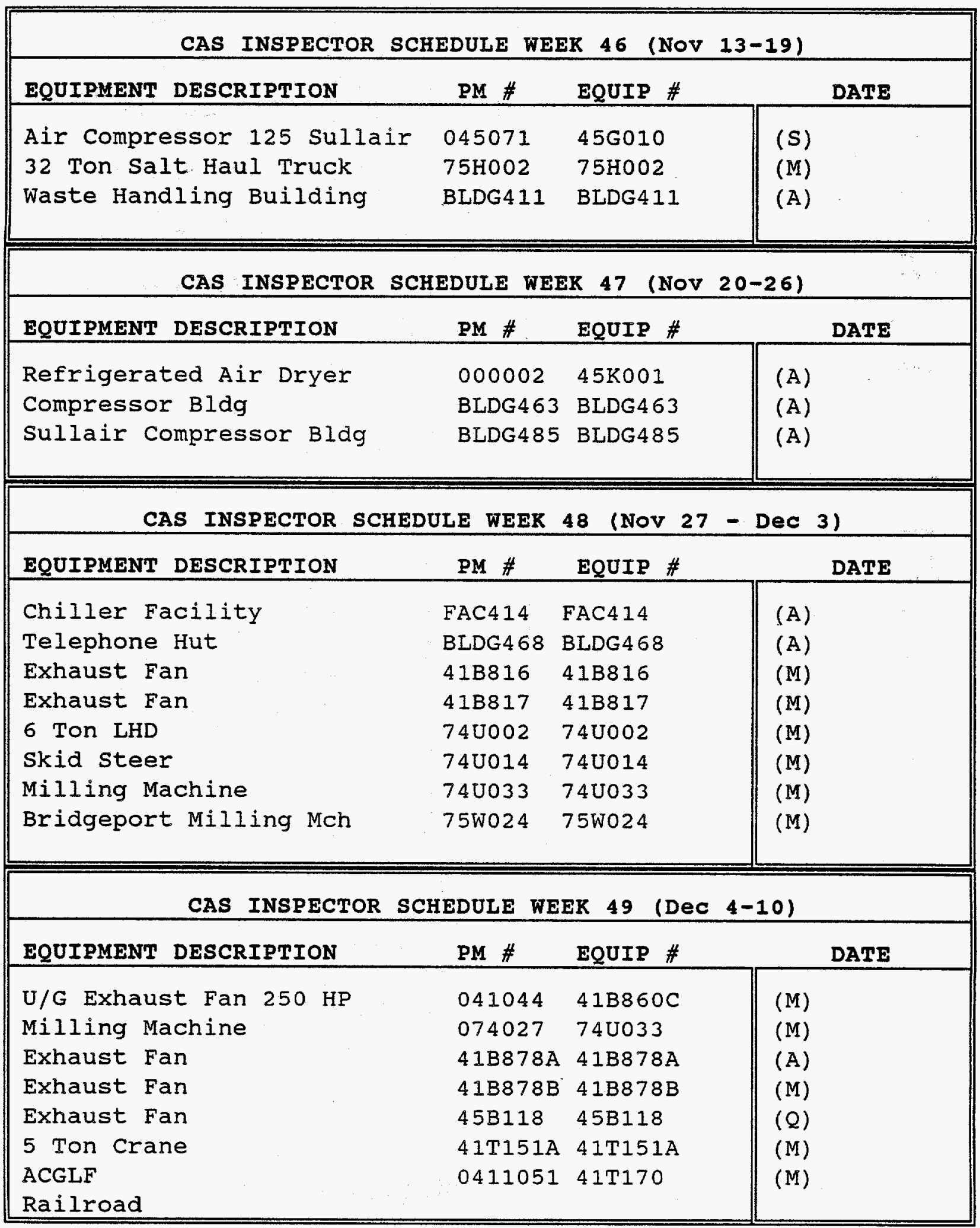


APPENDIX E INSPECTION SCHEDULE

\begin{tabular}{|c|c|c|}
\hline CAS INSPECTOR & SCHEDULE WEEK 50 & $11-17)$ \\
\hline EQUIPMENT DESCRIPTION & EOUIP \# & DATE \\
\hline Forklift 6 Ton & $074031 \quad 75 \mathrm{HOO1}$ & (A) \\
\hline 13 Ton Forklift & $41 \mathrm{H} 012 \mathrm{~B} \quad 41 \mathrm{H} 012 \mathrm{~B}$ & (A) \\
\hline Secondary Roads & FAC200 FAC200 & (A) \\
\hline Trailer Jockey & $41 \mathrm{HO} 30 \mathrm{~A} \quad 41 \mathrm{HO} 30 \mathrm{~A}$ & (M) \\
\hline Trailer Jockey & $41 \mathrm{HO} 3 \mathrm{OB} \quad 41 \mathrm{HO} 3 \mathrm{OB}$ & (M) \\
\hline CAS INSPECTOR & SCHEDULE WEEK 51 (DeC & $18-24)$ \\
\hline EQUIPMENT DESCRIPTION & EQUIP \# & DATE \\
\hline $\begin{array}{l}\text { Astro Acr Welder } \\
\text { Camp Report }\end{array}$ & $41 Y 115$ & (A) \\
\hline CAS INSPECTOR & SCHEDULE WEER 52 (DeC & $25-31)$ \\
\hline EQUIPMENT DESCRIPTION & EQUIP \# & DATE \\
\hline Camp Report & & \\
\hline
\end{tabular}


APPENDIX E

INSPECTION SCHEDULE

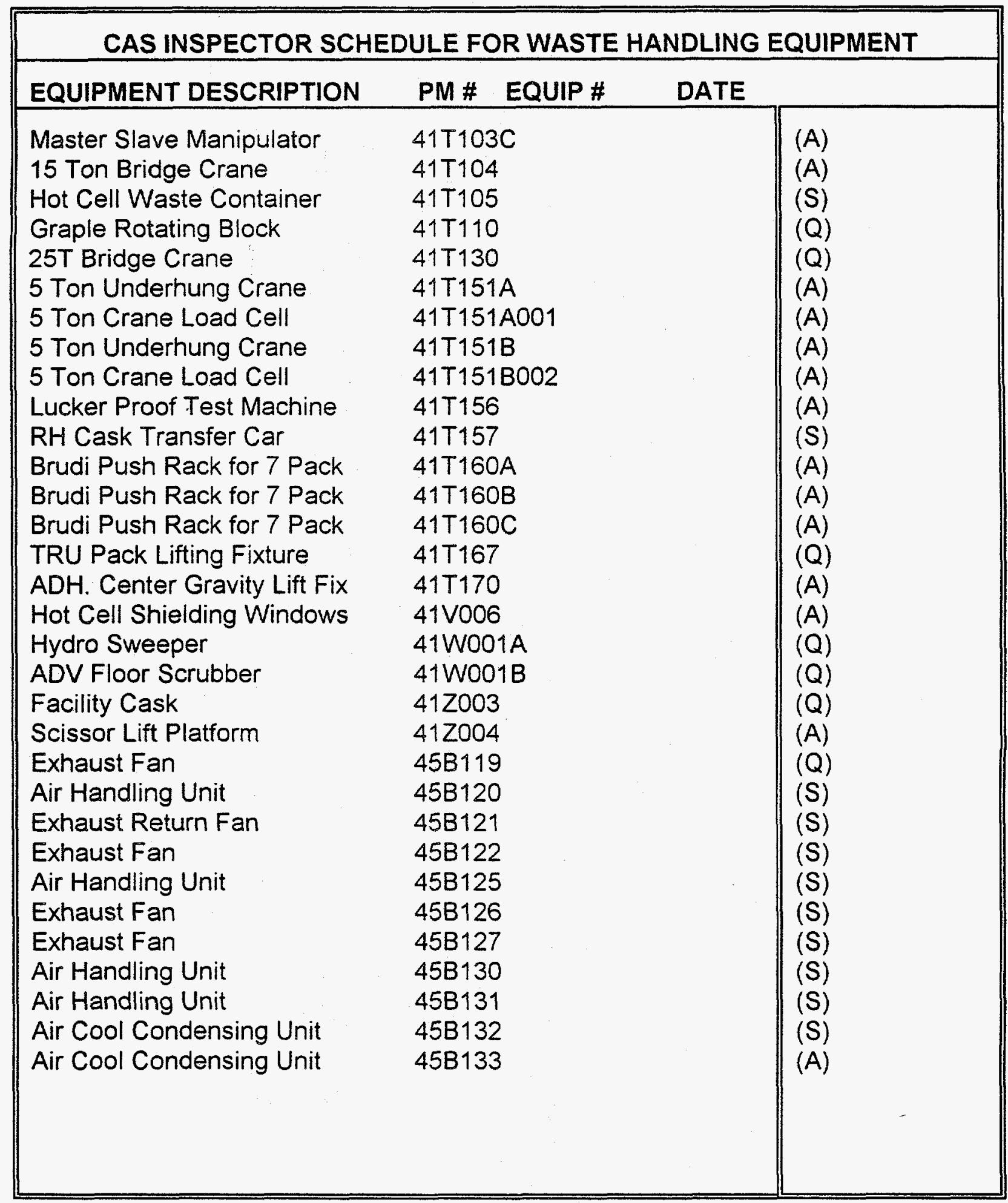

